15. Burdo O. et al. (2016) The technologies of targeted energy supply in food industry // MOTROL. Com. Mot. Energ. Agric. Vol. 18 , № 8. P. 7-14.

16. Burdo O. et al. (2017) Development of wave technologies to intensify heat and mass transfer processes // EasternEuropean J. Enterp. Technol. Vol. 4, № 11-88.

doi:

\title{
ПІДВИЩЕННЯ ЕФЕКТИВНОСТІ ПРОЦЕСУ ОЧИСТКИ ВОДИ МЕТОДОМ БЛОЧНОГО ВИМОРОЖУВАННЯ
}

\author{
Трішин Ф.А., к.т.н., доцент, Светлічний П.І., к.т.н., доцент, Трач О.Р., старший викладач, \\ Орловська Ю.В., аспирант \\ Одеська національна академія харчових технологій, м. Одеса
}

\begin{abstract}
Анотація. Метою роботи є вивчення впливу ультразвуку малої потужності на процеси тепло- $і$ масообміну в установках блочного виморожування. Доведено, щуо ефективним засобом управління потоками енергї при блочному виморожування є застосування ультразвукового поля. Зафіксовано збільшення маси блоку льоду завдяки зростанню коефіцієнту масовіддачі на 15-20\%, зниження вмісту солей в стоках на 40\% та зниження пористості блоку льоду на 22\% Визначено залежність кінетики сепарування та кристалізації блоку льоду від потужності і частоти ультразвуку. Методами теорії подібності проведено узагальнення отриманих експериментальних даних. Отримана залежність $S t_{w}\left(E u_{w}, G r\right)$, що може бути використана для оптимізації та конструкторських розрахунків установок блочного виморожування з ультразвуковим інтенсифікатором в діапазоні частот від 20 до 60 кГи.
\end{abstract}

Ключові слова: моделювання, кристалізація, пористість, концентрація, температура, теплопередача.

\section{INCREASING THE EFFICIENCY OF THE WATER PURIFICATION PROCESS BY BLOCK FREEZING METHOD}

\author{
Trishyn F.A., PhD in Tech.Sci., Associate prof., Svetlichniy P.I., PhD in Tech.Sci., Associate prof., \\ Trach O.R., senior teacher, Orlovskaya Yu.V., postgraduate student \\ Odessa national academy of food technologies, Odessa, Ukraine
}

\begin{abstract}
For the period from 1900 to 1995, freshwater consumption in the world increased six-fold. Scientists predict that by 2030, $47 \%$ of the population of the Earth will have difficulty with access to drinking water. In that regard, the development of energy-efficient methods for obtaining purified water is of practical and scientific interest. $96 \%$ of total desalinated water in the world is obtained with distillation desalination plants, $2.9 \%$ - with electrodialysis plants, $1 \%$ - by reverse osmosis plants, and $0.1 \%$ - with the share freezing and ion exchange desalination plants. There is a growing interest in the technologies of block freezing for water cleaning. Systems of this type are characterized by simplicity of design, compactness, and energy efficiency. Over the last years, the interest in intensification of the processes which use ultrasonic radiation has been increased. Despite a wide range of studies, the use of moderate and low power ultrasound to crystallize and separate water is still insufficiently studied. The objective of this work is to study the influence of the low power ultrasound on the processes of heat and mass exchange in block freezing units. In experiments, an ultrasonic generator with variable frequency (from 10 to $80 \mathrm{KHz}$ ) and power used. The use of ultrasonic field has been proved to be an effective method of controlling energy flow during block freezing. It has been established that ultrasound increases the mass of ice, and intensifies the freezing process. It has been observed that the ice block mass increases when the weight ratio increases by 15-20\%, and the salt content in the drains and the ice block porosity decrease by $40 \%$ and by $22 \%$, respectively. It has been determined that there is dependence of the separation and crystallization kinetics of the ice block from the ultrasound power and frequency. Low temperature separation under the influence of ultrasonic fields characterized by significantly lower energy consumption compared with traditional distillation. To summarize the obtained experimental data, the methods of similarity theory have been used. The dependence $S t_{w}\left(E u_{w}, G r\right)$ has been obtained which can be used for optimization and design calculations of block freezing units with ultrasonic intensifier within the frequency range of $20 \mathrm{KHz}$ to $60 \mathrm{KHz}$.
\end{abstract}

\footnotetext{
Наукові праці, Том 82, випуск 1
} 


\section{Одеська національна академія харчових технологій ІННОВАЦЙНЕ ОБЛАДНАННЯ ХАРЧОВИХ, ФАРМАЦЕВТИЧНИХ, ХІМІЧНИХ ТА ПАРФУМЕРНИХ ВИРОБНИЦТВ}

Keywords: modeling, crystallization, porosity, concentration, temperature, heat transfer.

Вступ. Наразі в світі значно збільшуються масштаби споживання води, i, відповідно, іï дефіцит, що може стати причиною погіршення умов проживання та уповільнити економічний розвиток країн, що зазнають нестачі питних ресурсів. В першу чергу це стосується густонаселених регіонів Землі, де відносно небагато великих річок і зосереджена велика кількість промислових підприємств. За період з 1900 по 1995 рік споживання прісної води в світі збільшилося в шість разів, що в два рази випереджає темпи приросту населення. Вже сьогодні близько третини населення планети відчуває проблеми з отриманням якісної прісної води, оскільки проживає в країнах, які споживають воду в обсязі, що на 10 відсотків перевищує наявні у них запаси. Прогнозують, що до 2030 року ситуація істотно погіршиться та ця цифра буде складати вже 47\%, або майже 4 млрд. осіб [1].

У 1970 -ті роки на одного жителя земної кулі припадало в середньому близько 11 тис. м ${ }^{3}$ на рік поверхневих вод, в 1980-ті - вже 8,7 тис., а в кінці XX ст. $-6,5$ тис. м³ на рік $[2,3,4]$. В зв'язку з такою ситуацією розробка енергоефективних способів отримання очищеної води представляє практичний та науковий інтерес. 3 усього обсягу опрісненої води, що отримується зараз в світі, 96\% припадає на частку дистиляційних опріснювальних установок, $2,9 \%$ - електродіалізних, $1 \%$ - оберненого осмосу і $0,1 \%$ - на частку виморожуючих та іонообмінних опріснювальних установок [5]. Зазначимо, що через низьку енергоефективність дистиляційних опріснювальних установок частка альтернативних способів очищення води постійно зростає.

Оскільки, витрати енергії на утворення льоду в 6,7 разів менші ніж витрати енергії на випаровування, то виморожуючі установки мають значні перспективи розвитку. В першу чергу це стосується систем блочного виморожування, оскільки вони характеризуються простотою конструкції, компактністю та енергетичною ефективністю. Подальше поширення цих установок можливе при появі нових способів підвищення їх енергоефективності.

Літературний огляд. В останні роки підвищується інтерес до технологій інтенсифікації процесів за допомогою ультразвукового випромінювання, зокрема, з використанням потужного ультразвуку. Потужний ультразвук характеризується потужністю від $10 \mathrm{Bт} / \mathrm{cm}^{2}$ i до $1000 \mathrm{BT} / \mathrm{cm}^{2}$, в залежності від області застосування [6,7]. При цьому частоти можуть бути надзвичайно низькими, порядку тисяч герц. Типові робочі частоти для більшості систем на основі потужного ультразвуку становлять від 20 до 100 кГц, хоча в деяких випадках застосовуються і частоти до 10 кГц і вище 500 кГц.

В деяких системах очищення або сонохіміі можна зустріти навіть мегагерцовий діапазон. Застосування потужного ультразвуку до рідких середовищ викликає ряд широко відомих ефектів: акустичну кавітацію [8,9], ультразвуковий капілярний ефект [10,11,12], сонолюмінісценцію [11], прискорення процесів дифузії [13], а також ряд хімічних ефектів [14]. Встановлено, що ультразвукове випромінювання має позитивний вплив на процес вирощування кристалів з розчину $[15,16]$, покращує процес очищення води від забруднень [17], підвищуе ефективність різноманітних процесів обробки продуктів в харчовій промисловості [18,19,20,21,22], а також покращує процеси тепло- і масопереносу [23].

Мета роботи та аналіз схеми процесу. Незважаючи на широкий спектр досліджень, все ще недостатньо вивчене застосування ультразвуку середньої і малої потужності, а також застосування ультразвукового випромінювання до процесів кристалізації і сепарації води. Запропонована гіпотеза, що енергоефективність процесу блочного виморожування можна підвищити за допомогою впливу ультразвуку середньої і малої потужності. Передбачається, що організація локального впливу ультразвуковим генератором на поверхню фазового контакту «лід-вода», дозволить здійснювати формування блоку льоду з більш щільною упаковкою кристалів, а на стадії сепарування - більш ефективну евакуацію розчинів 3 пористого обсягу блоку льоду. Блок льоду - це своєрідна система з порами (капілярами), під впливом ультразвуку молекули незамерзлого сольового розчину розхитуються, що полегшує їх вихід з пористої структури блоку, це теоретично дозволяє значно скоротити час сепарування.

Розглянемо фізику процесу виморожування на прикладі базової установки блочного типу (рис.1).

Рівень температур процесу виморожування стабілізується регулюючим вентилем (РВ). Використання енергії льоду в даній схемі не передбачено, одна схема може бути легко вдосконалена для того, щоб теплота плавлення льоду використовувалась в холодильному циклі для зниження температури холодильного агента перед дроселюванням. 3 розчину на кристалізаторах формується блок кристалів льоду, після чого, розчин, що залишився видаляється з концентратору. Утворений блок льоду відокремлюється від кристалізатора та проходить етап гравітаційного сепарування. Нетривалий процес відтаювання супроводжується плавленням тонкого поверхневого шару блоку, вода, що утворилася внаслідок цього процесу, змиває розчин солі з поверхні блоку та капілярних об'ємів. Після цього проводиться розплавлення льоду та отримується очищена вода. Таким чином, можна забезпечити безперервний процес опріснення, процес легко механізувати, ним легко управляти.

Наукові праці, Том 82, випуск 1 Scientific Works, Volume 82, Issue 1 


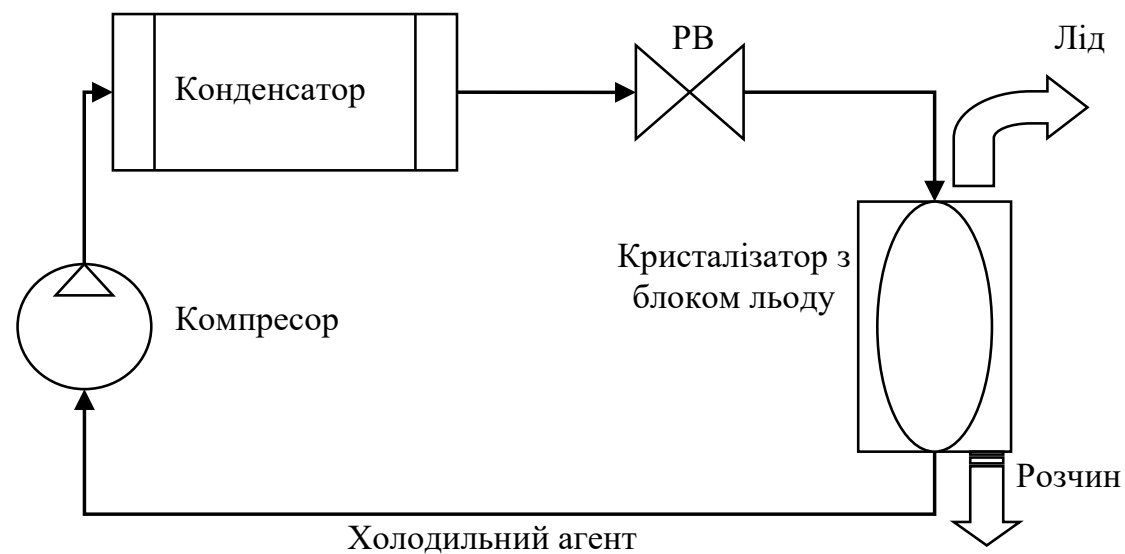

Рис. 1. Схема базової технології блочного виморожування.

В якості охолоджуючого середовища можна використовувати холодильний агент, наприклад, холодне повітря з навколишнього середовища. Інтерес представляють співвідношення матеріального балансу процесів кристалізації і сепарування, рівняння теплового балансу і термодинамічні умови фазового рівноваги в системі «розчин - лід». Розглянемо балансові моделі процесу блочного виморожування. На вхід в кристалізатор надходить розчин з концентрацією $\mathrm{X}_{\mathrm{s}}$ в кількості $\mathrm{G}_{\mathrm{s}}$ (рис. 2).

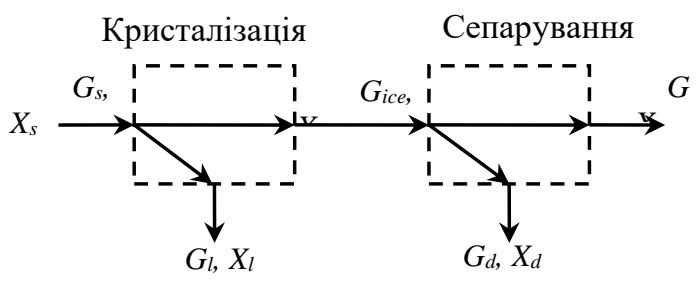

Рис.2. Схема матеріальних потоків.

3 концентратора виходить розчин 3 концентрацією $\mathrm{X}_{1}$ в кількості $\mathrm{G}_{1}$ i лід, маса якого $\mathrm{G}_{\text {ice. }}$

У порах льоду міститься рідина, концентрація якої в блоці льоду - Хісе. Після сепарування відокремлюються стоки в кількості $\mathrm{G}_{\mathrm{d}} 3$ концентрацією $\mathrm{X}_{\mathrm{d}}$.

Розплав льоду, маса якого $\mathrm{G}_{\mathrm{m}}$, має концентрацію $\mathrm{X}_{\mathrm{m}}$. На практиці легко вимірюються параметри: $\mathrm{G}_{\mathrm{s}}$, $\mathrm{X}_{\mathrm{s}}, \mathrm{G}_{\mathrm{l}}, \mathrm{X}_{\mathrm{l}}, \mathrm{G}_{\mathrm{d}}, \mathrm{X}_{\mathrm{d}}$. Для розрахунку інших параметрів складаються системи рівнянь.

Для процесу кристалізації:

$$
\left.\begin{array}{l}
G_{l}+G_{i c e}=G_{s} \\
G_{l} X_{l}+G_{i c e} X_{\text {ice }}=G_{s} X_{s}
\end{array}\right\}
$$

3 першого співвідношення в (1) знаходиться $\mathrm{G}_{\text {ice }}$, яке підставляється в друге рівняння $\mathrm{i}$, після нескладних перетворень, визначається зміст сухих речовин в блоці льоду:

$$
X_{\text {ice }}=\frac{G_{s} X_{s}-G_{l} X_{l}}{G_{s}-G_{l}}
$$

Для процесу сепарування:

$$
\left.\begin{array}{l}
G_{d}+G_{m}=G_{i c e} \\
G_{d} X_{d}+G_{m} X_{m}=G_{i c e} X_{i c e}
\end{array}\right\}
$$

Значення $\mathrm{G}_{\text {ice }} \mathrm{i} \mathrm{X}_{\mathrm{ice}}$ отримані з розрахунку кристалізатора. Аналогічно (9) знаходяться концентрації солей в розплаві льоду:

$$
X_{m}=\frac{G_{i c e} X_{i c e}-G_{d} X_{d}}{G_{i c e}-G_{d}}
$$

Розглянемо схему енергетичних потоків в установці блочного виморожування для демінералізації води.

Наукові праці, Том 82, випуск 1 Scientific Works, Volume 82, Issue 1 


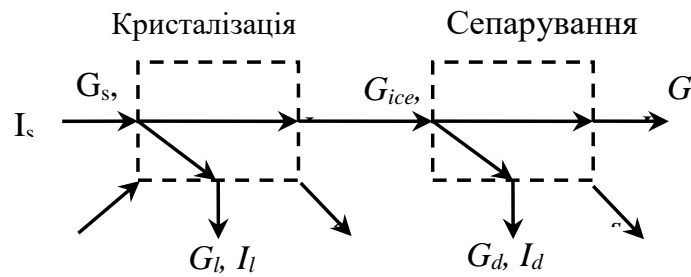

Рис. 3. Схема енергетичних потоків.

В технологічну лінію (рис. 3) ззовні надходить 2 потоки енергії: з вихідною сировиною $\left(Q_{m}=G_{s} I_{s}\right)$ i електрична $(\mathrm{N})$. У загальному випадку енергія може витрачатися на роботу компресора, систему термостатування при сепарування блоку льоду і на роботу зовнішніх інтенсифікаторів процесу кристалізації і сепарування. Енергія N витрачається на охолодження розчину від початкової температури до температури кристалізації $(\mathrm{Qr})$ і безпосередньо на процес льодоутворення $\left(Q_{c}=G_{i c e} \Omega\right)$.

Результати експериментальних досліджень. В дослідах з вивчення впливу ультразвукового поля на фізичні параметри процесу кристалізації та сепарування. був застосований ультразвуковий генератор зі змінною частотою (від 10 до 80 кГц).

Встановлено, що ультразвук збільшує масу льоду, та інтенсифікує процес виморожування (рис.4). 20 КГц.

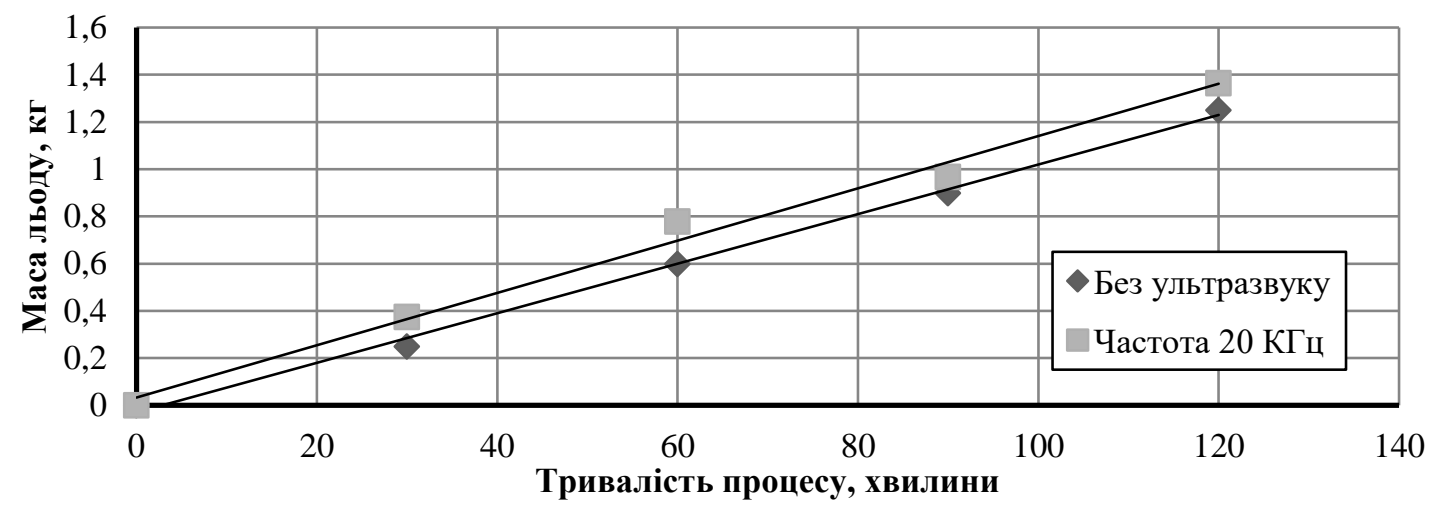

Рис. 4. Вплив ультразвуку на масу блоку льоду.

Під впливом ультразвуку частотою 20 кГц маса блоку льоду зростає швидше ніж в контрольному випадку (рис. 4). Аналогічна залежність спостерігається і для інших частот.

Важливим параметром, що характеризує процес кристалізації є коефіцієнт масовіддачі:

$$
\beta=\frac{V}{\tau S_{i c e}\left(X_{c r}-X_{c}\right)}
$$

де $\tau$ - тривалість процесу, $\mathrm{S}_{\mathrm{ice}}$ - поверхня блоку льоду, $\mathrm{V}$ - його об' $€ \mathrm{M}, \mathrm{X}_{\mathrm{cr}}-$ вміст солей при кріоскопічній температурі, a $\mathrm{X}_{\mathrm{c}}$ - вміст солей при поточній температурі.

Отримано залежність коефіцієнту масовіддачі від частоти (рис. 5). Можна побачити, що коефіцієнт масовіддачі зростає при підвищенні частоти від 20 до 60 кГц.

Для проведення конструкторських розрахунків установок блочного виморожування важливо отримати формулу, що характеризує параметри апарату. Для цього звернемось до теорії подібності та розглянемо залежність $\mathrm{St}_{\mathrm{w}}\left(\mathrm{Eu}_{\mathrm{w}}, \mathrm{Gr}\right)$, де індекс w означає хвильовий.

Враховуючи залежність швидкості від параметрів хвильового перемішування та опираючись на теорію подібності та літературні джерела [24,25] отримаємо наступну формулу для хвильового числа Ейлеpa:

$$
E u_{w}=\frac{q_{v}}{\mu f^{2}}
$$

Конвективні процеси в апараті характеризує число Грасгофа:

$$
G r=\frac{g \beta_{v} \Delta t h^{3}}{v^{2}}
$$


Одеська національна академія харчових технологій

ІННОВАЦИЙНЕ ОБЛАДНАННЯ ХАРЧОВИХ, ФАРМАЦЕВТИЧНИХ, ХІМІЧНИХ ТА ПАРФУМЕРНИХ ВИРОБНИЦТВ

В якості розміру, що характеризує параметри апарату $\mathrm{h}$, виберемо більший розмір виморожуючої установки, тобто довжину, $\beta_{\mathrm{v}}$ - коефіцієнт об'ємного розширення.

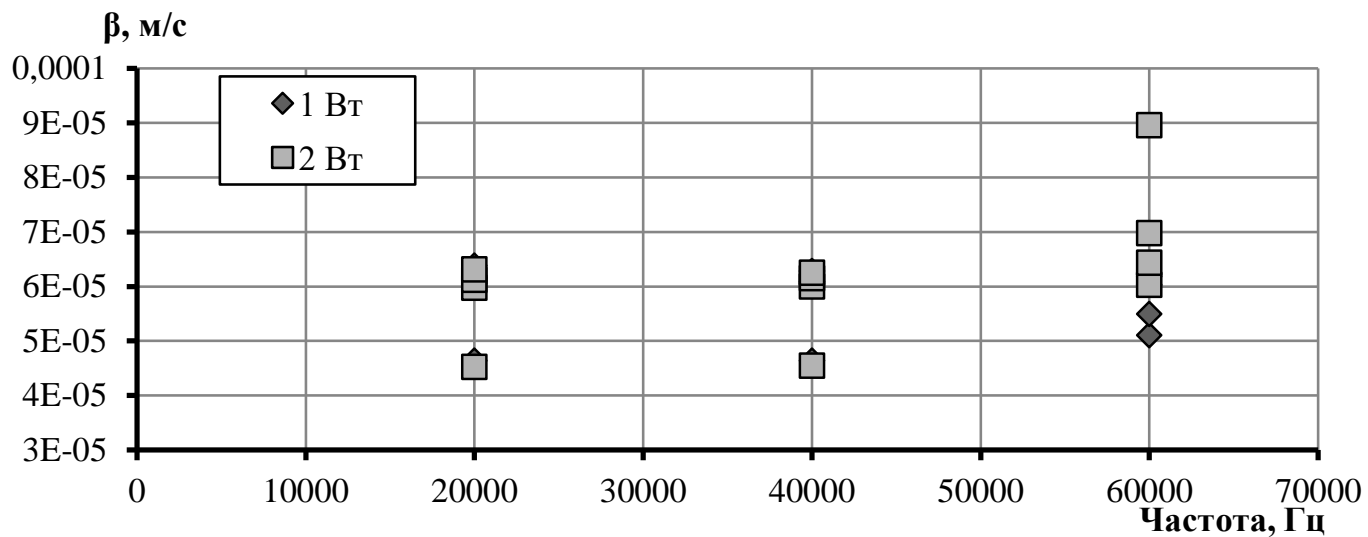

Рис. 5. Залежність коефіціснту масовіддачі від частоти ультразвукового випромінювання при різній потужності.

Число Стантона хвильового, з якого розраховується коефіцієнт масовіддачі ( $\beta$ ) визначається за формулою:

$$
S t_{w}=\frac{\beta}{d f}
$$

Використовуючи теорію подібності, та запропоновані хвильові числа, що приведені вище, отримано рівняння для визначення хвильового числа Стантона:

Відповідно розраховується за формулою:

$$
S t_{w}=0.56 G r^{-0.65} E u_{w}{ }^{0.32}
$$

Формула (9) може бути використана для оптимізації та конструкторських розрахунків установок блочного виморожування з ультразвуковим інтенсифікатором в діапазоні частот від 20 до 60 кГц. Наступним етапом роботи було дослідження процесу сепарації [25]. Доказано, що застосування ультразвуку значно знижує концентрацію солей в стоках, що підвищує енергетичну ефективність процесу (рис.6).

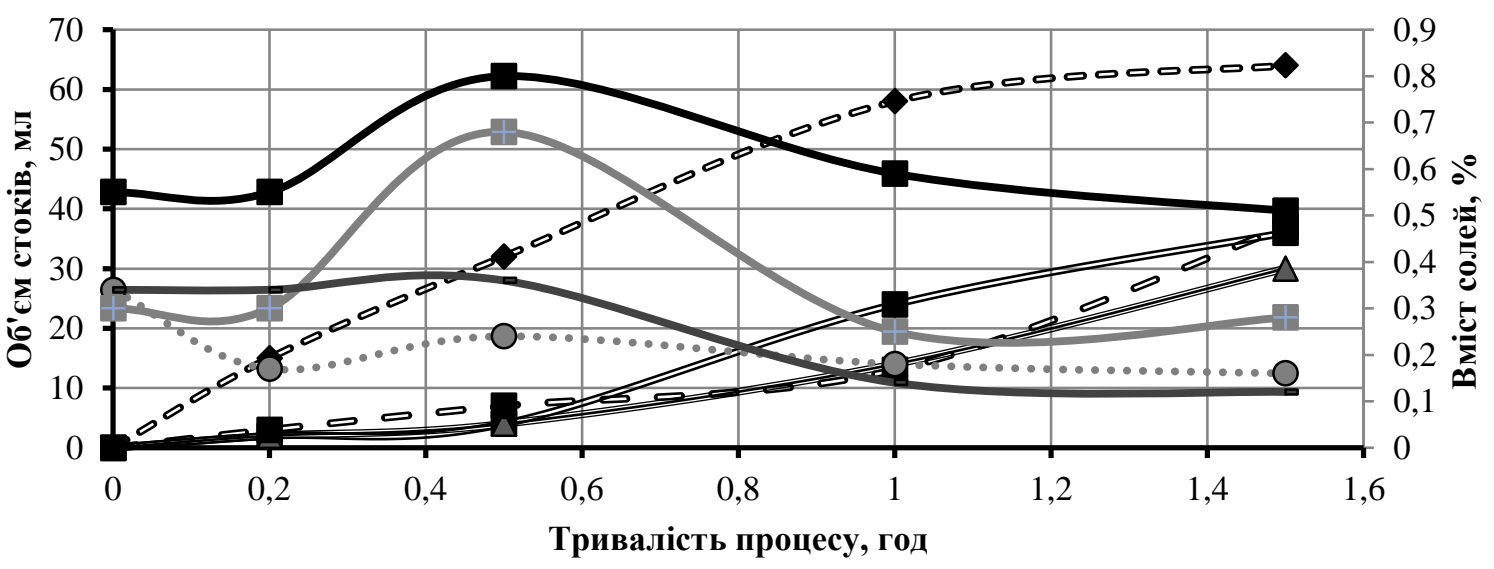

$$
\begin{aligned}
& \multimap \text { Без ультразвуку (об'єм стоків, мл) — Частота } 20 \text { КГц (об'єм стоків, мл) } \\
& \Longrightarrow \text { Частота } 60 \text { КГц (об'єм стоків, мл) صㄷ Частота } 80 \text { Кгц (об'єм стоків, мл) } \\
& \text { - Без ультразвуку (вміст солей,\%) •О. Частота } 20 \text { КГц (вміст солей,\%) } \\
& \longrightarrow \text { Частота } 60 \text { Кгц (вміст солей,\%) — Частота } 80 \text { Кгц (вміст солей,\%) }
\end{aligned}
$$

Рис.6. Вміст солей в стоках та об'єм стоків для різних параметрів УЗ випромінювача. 


\section{Одеська начіональна академія харчових технологій \\ ІННОВАЦІЙНЕ ОБЛАДНАННЯ ХАРЧОВИХ, ФАРМАЦЕВТИЧНИХ, ХІМІЧНИХ ТА ПАРФУМЕРНИХ ВИРОБНИЦТВ}

Отримані результати (рис.6) показують, що ультразвук сприяє більш щільній упаковці кристалів та зменшує пористість сформованого блоку льоду.

\section{Висновки.}

В рамках роботи проведено дослідження процесу кристалізації та сепарування блоку льоду в ультразвуковому полі. Експериментально показано, що використання ультразвукового інтенсифікатора дозволяє підвищити енергоефективність процесу, зокрема зафіксовано збільшення маси блоку льоду завдяки зростанню коефіцієнту масовіддачі на $15-20 \%$, зниження вмісту солей в стоках на $40 \%$ та зниження пористості блоку льоду на $22 \%$. Це можна пояснити меншим значенням пористості блоку, більш швидким його наморожуванням і більш щільною упаковкою кристалів. При цьому слід зауважити, що низькотемпературне розділення під впливом ультразвукових полів характеризується витратами енергії значно нижчими в порівнянні 3 традиційною дистиляцією. Для процесу кристалізації було отримано залежність $\mathrm{St}\left(\mathrm{Eu}_{\mathrm{w}}, \mathrm{Gr}\right)$, яка дозволяє проводити оптимізацію та конструкторські розрахунки установок блочного виморожування з ультразвуковим інтенсифікатором в діапазоні частот від 20 до 60 кГц.

\section{Література}

1. Four billion people facing severe water scarcity [Електронний ресурс] // Science Advances. - 2016. - Режим доступу до ресурcy: http://advances.sciencemag.org/content/2/2/e1500323.full.1

2. Хвесик М. А. Водні ресурси - інвестиція сьогодення і перспектива майбутнього / М. А. Хвесик, В. М. Мандзик. // Інвестиції: практика та досвід. - 2009. - №1. - С. 2-8.

3. Шимко Д. А. Проблема дефицита пресной воды в мире / Д. А. Шимко, О. Б. Бондарчик. // AlfaBuild. - 2017. - №1. - С. 715.

4. Данилов-Данильян В. И. Глобальная проблема дефицита пресной воды / В. И. Данилов-Данильян. // Век глобализации. 2008. - №1. - C. 45-56.

5. Мосин О. В. Установки опреснения морской воды / О. В. Мосин. // Сантехника, Отопление, Кондиционирование. - 2012. - №1.

6. Karl F. Graff, Juan A. Gallego-Juárez. Power Ultrasonics. Applications of High-intensity Ultrasound. Woodhead Publishing, 2014, 1166 .

7. J. David N. Cheeke. Fundamentals and Applications of Ultrasonic Waves, Second Edition. CRC series in pure and applied physics, 2017, 504p.

8. Leighton T.G. The Acoustic Bubble. London: Academic Press, 1994. 611 p.

9. Choi, P. K. (2017). Sonoluminescence and acoustic cavitation. Japanese Journal of Applied Physics, 56(7S1), 07JA01.

10. Dezhkunov, N. V., \& Leighton, T. G. (2004). Study into correlation between the ultrasonic capillary effect and sonoluminescence. Journal of Engineering Physics and Thermophysics, 77(1), 53-61.

11. Dezhkunov, N. V., Francescutto, A., Ciuti, P., \& Ignatenko, P. (2003). Ultrasonic capillary effect and sonoluminescence. In Proc. of 5-th World Congress on Ultrasonics (WCU 2003). Paris (pp. 597-600).

12. Lang, R. J. (1962). Ultrasonic atomization of liquids. The journal of the acoustical society of America, 34(1), 6-8.

13. Mason T.J., Lorimer J.P. Applied Sonochemistry: Uses of Power Ultrasound in Chemistry and Processsing. N.Y.: Wiley\&Sons, 2002. 314 p.

14. Suslick, K. S. (1989). The chemical effects of ultrasound. Scientific American, 260(2), 80-87.

15. Ubbenjans B., Frank-Rotsch Ch., Virbulis J., Nacke B., Rudolph P. Influence of Ultrasonic Treatment on Crystal Growth From Melt. International Scientific Colloquium, Modelling for Material Processing, Riga, September 16-17, 2010 , pp. 79-84.

16. John R.G. Sander, Brad W. Zeiger, Kenneth S. Suslick. (2014) Sonocrystallization and sonofragmentation. Ultrasonics Sonochemistry, 21, pp. 1908-1915.

17. A. Hiratsuka and D. Pathak, "Application of Ultrasonic Waves for the Improvement of Water Treatment," Journal of Water Resource and Protection, Vol. 5 No. 6, 2013, pp. 604-610. doi: 10.4236/jwarp.2013.56061.

18. Deora, NS, Misra, NN, Deswal, A, Mishra, HN, Cullen, PJ \& Tiwari BK (2013) Ultrasound for Improved Crystallisation in Food Processing, Food Engineering Reviews, 5(1):36-44.

19. Wagh, Ashwini \& Birkin, Peter \& Martini, Silvana. (2016). High-Intensity Ultrasound to Improve Physical and Functional Properties of Lipids. Annual review of food science and technology. 7. 10.1146/annurev-food-041715-033112.

20. Chemat, Farid \& , Zill-e-Huma \& Khan, Muhammad. (2010). Applications of Ultrasound in Food Technology: Processing, Preservation and Extraction. Ultrasonics sonochemistry. 18. 813-35. 10.1016/j.ultsonch.2010.11.023.

21. Kasaai, M. (2013) Input power-mechanism relationship for ultrasonic Irradiation: Food and polymer applications. Natural Science, 5, 14-22. doi: 10.4236/ns.2013.58A2003.

22. Ultrasonication Affects Crystallization Mechanisms and Kinetics of Anhydrous Milk Fat. Rikke P. Frydenberg, Marianne Hammershøj, Ulf Andersen, and Lars Wiking. Crystal Growth \& Design 201313 (12), 5375-5382. DOI: 10.1021/cg4012923.

23. Kentish, Sandra \& Feng, Hao. (2014). Applications of Power Ultrasound in Food Processing. Annual review of food science and technology. 5. 10.1146/annurev-food-030212-182537.

24. Техника блочного вымораживания / О. Г.Бурдо, С. И. Милинчук, В. П. Мордынский, Д. А. Харенко. - Одесса: Полиграф, 2011. - 294 c.

25. Бурдо О. Г. Холодильные технологии в системе АПК / О. Г. Бурдо. - Одесса: Полиграф, 2009. - 288 с.

26. Управление потоками энергии в низкотемпературных разделительных установках. // Проблемы региональной энергетики. - 2018. - №1. - C. 72-86.

\section{References}

1. Mekonen, M. M. \& Hoekstra, A. Y. (2016). Four billion people facing severe water scarcity. Science Advances,2(2). Available at: http://advances.sciencemag.org/content/2/2/e1500323.full.1.

2. Hvesik M. A. (2009). Vodni resursi - Investitsiya sogodennya i perspektiva maybutnogo. Investitsiyi: praktika ta dosvid, 1, $2-8$.

3. Shimko D. A. (2017). Problema defitsita presnoy vody v mire . AlfaBuild. - №1. - C. 7-15.

4. Danilov-Danilyan V. I. (2008). Globalnaya problema defitsita presnoy vody. Vek globalizatsii. №1. 45-56. 


\title{
Одеська національна академія харчових технологій ІННОВАЦЙНЕ ОБЛАДНАННЯ ХАРЧОВИХ, ФАРМАЦЕВТИЧНИХ, ХІМІЧНИХ ТА ПАРФУМЕРНИХ ВИРОБНИЦТВ
}

5. Mosin O. V. (2012). Ustanovki opresneniya morskoy vody - №1.

6. Karl F. Graff, Juan A. Gallego-Juárez.(2014). Power Ultrasonics. Applications of High-intensity Ultrasound. Woodhead Publishing, 1166.

7. J. David N. Cheeke.(2017). Fundamentals and Applications of Ultrasonic Waves, Second Edition. CRC series in pure and applied physics, 504

8. Leighton T.G.(1994). The Acoustic Bubble. London: Academic Press, 611.

9. Choi, P. K. (2017). Sonoluminescence and acoustic cavitation. Japanese Journal of Applied Physics, 56(7S1), 07JA01.

10. Dezhkunov, N. V., \& Leighton, T. G. (2004). Study into correlation between the ultrasonic capillary effect and sonoluminescence. Journal of Engineering Physics and Thermophysics, 77(1), 53-61.

11. Dezhkunov, N. V., Francescutto, A., Ciuti, P., \& Ignatenko, P. (2003). Ultrasonic capillary effect and sonoluminescence. In Proc. of 5-th World Congress on Ultrasonics (WCU 2003). Paris (pp. 597-600).

12. Lang, R. J. (1962). Ultrasonic atomization of liquids. The journal of the acoustical society of America, 34(1), 6-8.

13. Mason T.J., Lorimer J.P.(2002). Applied Sonochemistry: Uses of Power Ultrasound in Chemistry and Processsing. N.Y.: Wiley\&Sons, 314.

14. Suslick, K. S. (1989). The chemical effects of ultrasound. Scientific American, 260(2), 80-87.

15. Ubbenjans B., Frank-Rotsch Ch., Virbulis J., Nacke B., Rudolph P.(2010). Influence of Ultrasonic Treatment on Crystal Growth From Melt. International Scientific Colloquium, Modelling for Material Processing, Riga, 79-84.

16. John R.G. Sander, Brad W. Zeiger, Kenneth S. Suslick. (2014) Sonocrystallization and sonofragmentation. Ultrasonics Sonochemistry, 21, pp. 1908-1915.

17. Hiratsuka A. and Pathak D. (2013), "Application of Ultrasonic Waves for the Improvement of Water Treatment," Journal of Water Resource and Protection, Vol. 5 No. 6, 604-610. doi: 10.4236/jwarp.2013.56061.

18. Deora, NS, Misra, NN, Deswal, A, Mishra, HN, Cullen, PJ \& Tiwari BK (2013) Ultrasound for Improved Crystallisation in Food Processing, Food Engineering Reviews, 5(1):36-44.

19. Wagh, Ashwini \& Birkin, Peter \& Martini, Silvana. (2016). High-Intensity Ultrasound to Improve Physical and Functional Properties of Lipids. Annual review of food science and technology. 7. 10.1146/annurev-food-041715-033112.

20. Chemat, Farid \& , Zill-e-Huma \& Khan, Muhammad. (2010). Applications of Ultrasound in Food Technology: Processing, Preservation and Extraction. Ultrasonics sonochemistry. 18. 813-35. 10.1016/j.ultsonch.2010.11.023.

21. Kasaai, M. (2013) Input power-mechanism relationship for ultrasonic Irradiation: Food and polymer applications. Natural Science, 5, 14-22. doi: 10.4236/ns.2013.58A2003.

22. Rikke P.(2013). Ultrasonication Affects Crystallization Mechanisms and Kinetics of Anhydrous Milk Fat. Frydenberg, Marianne Hammershøj, Ulf Andersen, and Lars Wiking. Crystal Growth \& Design 13 (12), 5375-5382. DOI: 10.1021/cg4012923.

23. Kentish, Sandra \& Feng, Hao. (2014). Applications of Power Ultrasound in Food Processing. Annual review of food science and technology. 5. 10.1146/annurev-food-030212-182537.

24. Burdo O. G., Milinchuk S. I., Mordyinskiy V. P., Harenko D. A. (2011). Tehnika blochnogo vyimorazhivaniya. - 294.

25. Burdo O. G. (2009). Holodilnyie tehnologii v sisteme APK. -288 c.

26. Trishyn F.A., Trach O. R., Orlovskaya Yu. V.(2018). Upravlenie potokami energii v nizkotemperaturnyh razdelitalnyh ustanovkah. Problemi regionalnoy energetiki. №1. 72-86.

doi:

\section{ИССЛЕДОВАНИЕ ЭНЕРГОТЕХНОЛОГИЙ ПРОЦЕССОВ ОБЕЗВОЖИВАНИЯ РАСТИТЕЛЬНОГО СЫРЬЯ}

\author{
Гаврилов А.В. ${ }^{1}$, к.т.н., доцент, Безбах И.В. ${ }^{2}$, к.т.н., доцент, Мордынский В.П. ${ }^{2}$, к.т.н., доцент, \\ Бурдо О.Г. ${ }^{2}$, д.т.н., проф. \\ ${ }^{1}$ Академия биоресурсов и природопользования «КФУ им. В.И. Вернадского», \\ ${ }^{2}$ Одесская национальная академия пищевых технологий, г. Одесса
}

\begin{abstract}
Аннотация. Рассмотрены мировые тенденции на рынке сушеных продуктов и концентратов. Анализируются энерготехнологии основных процессов обезвоживания - выпарки и сушки. Сравниваются современные технологи обезвоживания и обсуждаются научно-технические противоречия процессов выпарки и сушки. Показаны энергетические преимущества выпарки и ограничения по конечному влагосодержанию готового продукта. Приведень модели материальных балансов при комбинированньх технологиях «выпарка - сушка». Представлены инновационные разработки техники обезвоживания - термомеханический агрегат и микроволновой вакуум-выпарной аппарат. Обсуждаются конструктивные варианты агрегата, возможности решать в нем параллельно задачи дробления, плющения, перемешивания и транспортировки продукта. Обоснованы механизмы интенсификации процесса тепломассопереноса в термомеханическом агрегате. Приведены значения коэффициентов теплопередачи в термомеханических агрегатах при обработке сырья в консервных, молочных, пищеконцентратных и винодельческих производствах. Проведено сравнение удельных энергетических затрат в термомеханическом агре-
\end{abstract}

